\title{
Administrasi Pendidik dan Tenaga Kependidikan (PTK) 1
}

\author{
Nadya Olivia Perrina \\ Universitas Negeri Padang \\ Indonesia \\ nadyaolivia2509.nogmail.com
}

\begin{abstract}
Abstrak-Educational personnel administration is the entire process of activities that are planned and carried out deliberately and conscientiously as well as carrying out coaching and continuous training of teachers and employees in schools or educational institutions.

Personnel administration, is a series of collaborative processes ranging from planning, organizing, mobilizing and supervising in the field of personnel by utilizing available and efficient resources, so that all school personnel contribute optimally to the achievement of established educational / school goals.
\end{abstract}

Keywords—Konsep dasar administrasi PTK, cuti, proses, gaji.

\section{Pendahuluan}

Pada hakikatnya aktivitas pendidikan selalu berlangsung dengan melibatkan unsur subyek atau pihakpihak sebagi aktor penting. Subyek penerima adalah peserta didik sedangkan subyek pemberi adalah pendidik. Seseorang yang menginginkan menjadi pendidik maka ia dipersyaratkan mempunyai kriteria yang di inginkan oleh duni pendidikan. Orang yang merasa terpanggil untuk mendidik maka ia mencintai peserta didiknya dan memiliki perasaan wajib dalam melaksanakan tugasnya disertai dengan dedikasi yang tinggi atau bertanggung jawab.

Kajian tentang pendidik mencakup beberapa hal antara lain pengertian dan sebutan istilah pendidik, kompetensi pendidik, kedudukan pendidik, hakekat tugas dan tanggung jawab guru, profesionalisme guru, organisasi profesi dan kode etik guru.

\section{Metode Penelitian}

Artikel ilmiah sesuai kaidahnya disusun denga sistimatis. Pada artikel ini penulis menggunakan metode studi litelatur yaitu mengumpulkan dan merangkum materi yang bersumber dari buku, jurnal, dan sumber lainnya yang terkait dengan ilmu adminstrasi pendidikan.

\section{KAJIAN TEORI DAN PEMBAHASAN}

\section{A. Pengertian Administrasi PTK}

Istilah personil disini hanya untuk golongan para petugas saja, yaitu guru dan pegawai lainnya.Setiap kelompok personalia tersebut mempunyai tugas dan tanggung jawab masing- masing, serta hubungan kerja yang jelas. Kepala sekolah biasanya dibantu oleh seorang atau beberapa orang wakil kepala sekolah yang mengkoordinir urusan/ kegiatan belajar mengajar, urusan kesiswaan, urusan sarana prasarana pendidikan, urusan hubungan sekolah dengan masyarakat. Sedangkan kelompok personalia non edukatif dipimpin oleh seorang kepala tata usaha. Administrasi personalia pendidikan merupakan seluruh proses kegiatan yang direncanakan dan diusahakan dengan sengaja dan bersungguh- sungguh serta melakukan pembinaan serta kontinu terhadap guru- gurudan pegawai yang ada disekolah atau lembaga pendidikan.

Administrasi personalia, adalah serangkaian proses kerja sama mulai dari perencanaan, pengorganisasian, penggerakan dan pengawasan dalam bidang personalia dengan mendayagunakan sumber daya yang ada dan efisien, sehingga semua personil sekolah menyumbang secara optimal bagi pencapaian tujuan pendidikan /sekolah yang telah ditetapkan.

Tenaga kependidikan menurut PP No 38 Tahun 1992 Pasal 1 adalah anggota masyarakat yang mengabdikan diri secara langsung dalam penyelenggaraan pendidikan. Lebih lanjut dalam Pasal 3 dinyatakan :

a. Tenaga kependidikan terdiri atas tenaga pendidik, pengelola satuan pendidikan, penilik, pengawas, peneliti dan pengembangan di bidang pendidikan pustakawan, laboran, teknisi sumber belajar dan pengajar.

b. Tenaga pendidik terdiri atas pembimbing, pengajar, dan pelatih

c. Pengelola satuan pendidikan terdiri atas kepala sekolah, direktur, ketua, rektor, dan pimpinan satuan pendidikan luar sekolah.

Jadi, dapat pemakalah simpulkan bahwa administrasi personalia itu adalah orang- orang yang melaksanakan sesuatu tugas, dan untuk mencapai tujuan penyelenggaran pendidikan sekolah itu dengan baik dan hasil yang diinginkan. 


\section{B. Proses Administrasi PTK}

\section{Rencana Pengadaan Personil}

Dalam upaya pengadaan personil pendidikan perlu dilakukan perencanaan yang matang, berapa jumlah personil yang dibutuhkan serta bidang keahlian apa yang diperlukan. Hal ini harus disesuaikan dengan kebutuhankebutuhan lembaga pendidikan yang bersangkutan.

Dalam membuat rencana pengadaan personil tersebut perlu dilakukan kegiatan- kegiatan sebagai berikut:

\section{a. Analisis Jabatan}

Analisis jabatan adalah usaha peninjauan terhadap semua jabatan atau pekerjaan- pekerjaan yang pada suatu lembaga pendidikan.Maksudnya agar dapat diketahui brapa jumlah personil yang dibutuhkan sesuai dengan jabatan dan keahlian yang diperlukan oleh lembaga pendidikan tersebut.

b. Inventarisasi personil

Inventarisasi personil adalah pencatatan atau pendaftaran jumlah maupun identitas personil yang ada.

c. Pengadaan personil

Menurut pasal 16 ayat 1 undang- undang No. 8 tahun 1974 tentang pokok- pokok kepegawaian menyatakan bahwa pengadaan pegawai negri sipil adalah usaha untuk melakukan pengisian formasi.

Perencanaan personalia mencangkup jumlah dan jenis keterampilan/ keahlian orang, ditempatkan pada pekerjaan yang terdapat pada waktu tertentu yang dalam janka panjang memberikan keuntungan bagi individu dan organisasi.

\section{Penataan, Pengangkatan dan penempatan calon pegawai/ personil}

Agar para personil dapat melaksanakan tugasnya secara tepat dan berhasil perlu ditata dengan memperhatikan beberapa hal seperti :

(a) Latar belakang pendidikan, ijazah/ keahliannya, dan interes kerjanya

(b) Pengalaman kerja( terutama yang diminati atau telah ditekuni)

(c) Kemungkinan pengemangan atau peningkatan kariernya

(d) Sikap atau penampilan dan sifat atau kepribadiannya. Demi suksesnya penataan itu dari pihak administrator/ pimpinan sekolah hendaknya dapat menyediakan situasi dan kondisi kerja yang layak/ memadai, tentram, aman serta nyaman sehingga para pegawai makin mencintai pekerjaannya.

Dalam Undang- Undang No 8 tahun 1974 pasal 19 dinyatakan bahwa pengangkatan dalam jabatan didasarkan atas prestasi kerja, disiplin kerja, kesetiaan, pengabdian, pengalaman dan di percaya, serta syaratsyarat obyektif lainnya.

Kegiatan yang dilakukan dalm pengangkatan dan penerimaan calon pegawai antara lain: a. Pelamar yang telah dinyatakan atau di tetapkan lulus dapat diterima atau diusulkan pengangkatannya menjadi calon pegawai oleh pejabat yang berwenang kepada Badan Administrasi Kepegawaian Negara( BAKN) setelah mendapat persetujuan maka yang bersangkutan diangkat menjadi calon pegawai dengan mengeluarkan surat keputusan pengangkatan sebagai calon pegawai sesuai dengan ketentuan peraturan pemerintah yang berlaku.

b. Penempatan pegawai/guru

Penempatan pegawai merupakan yang tidak mudah dan memerlukan pertimbangan dan pemikiran yang matang.

Ada beberapa kesulitan dalam penempatan pegawai, yaitu :

1) Pada umumnya pegawai memilih tempat bekerja dikota. Dan ingin melanjutkan pendidikannya kepada jenjang yang lebih tinggi. Disamping dikota tersedia sarana dan fasilitas untuk berkarya dan karya yang lain yang dapat menambah penghasilan

2) Dan pegawai enggan ditempat jauh dari kota, karena sarana dan fasilitas tidak memadai, sehingga kekurnggan guru didaerah tersebut

3) Adanya kecendrungan semakin bnyaknya siswasiswi yang masuk kesekolah guru yang tidak sebanding dengan siswanya.

4) Belum ada perencanaan yang matang dalam penempatan pegawai/ guru sehingga tidak terpenuhi jumlah guru sesuai dengan yang dibutuhkan.

5) Administrasi kepegawaian yang sangat birokratis, makanya sangat menghambat kelancaran prosedur pengangkatan dan penempatan guru atau personil pada umumnya.

Untuk mengatasi kesulitan dalam penempatan pegawai/ guru yang diatas dapat dilakukan hal- hal sebagai berikut :

1) Penempatan guru hendaknya didasarkan kepada hasil seleksi yang telah ditetapkan

2) Disesuaikan dengan kebutuhan sekolah yang bersangkutan

3) Jarak tempat tinggal guru dengan sekolah tidak begitu jauh atau tidak begitu sulit untuk datang kesekolah.

4) Perlu di pertimbangkan jenis kelamin dan status untuk sekolah tertentu

5) Latar belakang pendidikan dan pengalaman kerja guru sebelumnya di pertimbangkan.

c. Penghasilan / Gaji Guru

Berkenaan dengan penghasilan atau gaji yang akan diterima oleh pegawai perlu diperimbangkan hal- hal sebagai berikut:

1) Calon pegawai berhak memperoleh penghasilanatau gaji sesuai dengan peraturan perundang- undangan yang berlaku 
2) Pada saat pengangkatan seseorang calon pegawai sesuai dengan PP No. 6 tahun 1976 pasal 15, calon pegawai dapat memperhitungkan masa kerjanya kalau bersangkutan telah pernah mengabdi sebagai pegawai sebelum surat pengangkatannya sebagai pegawai negeri keluar

3) Hak gaji tersebut mulai berlaku pada bulan calon peawai yang bersangkutan secara nyata melaksanakan tugas.

- Calon pegawai yang bersangkutan sudah dianggap nyata melaksanakan tugasnyamulai saat tanggal yang diperintahkan atasannya

- Surat perintah perjalanan tugas tersebut dalam rangkap 3 .

4) Status kepegawaian dari pegawai/ guru

- Masa Percobaan

Masa percobaan yang lamanya sekurangkurangnya 1 tahun dan selama- lamanya 2 tahun

- Pengangkatan sebagai pegawai negeri/ guru negeri

Syarat- syarat yang harus dipenuhi oleh seseorang calon pegawai untuk diangkat sebagai pegawai negeri:

a) Telah menunjukkan kesetiaan dan ketaatan kepada pancasila, UUD 1945 negara dan pemerintah

b) Telah menunjukkan sikap dan budi pekerti yang baik

c) Telah menunjukkan kecakapan dalam melaksanakan tugas

d) Telah memenuhi syarat kesehatan jasmani dan rohani

3. Kenaikan pangkat, ujian Dinas dan angkat kredit bagi kenaikan jabatan fungsional guru

Ada berbagai jenis kenaikan pangkat, yaitu:

a. Kenaikan pangkat reguler, yaitu kenaikan pangkat yang diberikan pada PNS yang memenuhi syaratsyarat yang ditentukan tanpa memperhatikan jabatan yang dipangkunya.

b. Kenaikan pangkat pilihan, diberikan kepada PNS yang memangkupilihan jabatan structural atau jabatan fungsional tertentu.

c. Kenaikan pangkat istimewa adalah kenaikan pangkat yang diberikan pada PNS setingkat lebih tinggi dari pangkatnya semula

d. Kenaikan pangkat pengabdian merupakan kenaikan pangkat setingkat lebih tinggi sebagai penghargaan kepada PNS yang telah mencapai PNS.

\section{Pengembangan karir dan peningkatan mutu tenaga kependidikan}

a. Pentingnya pengembangan karir

Pengembangan karir tenaga kependidikan didasarkan atas kemanfaatan dan pemenuhan kebutuhan lembaga pendidikan, melalui pengembangan karir tersebut diharapkan:

1) Mutu dan antusias guru dalam melaksanakan tugas akan semakin tumbuh

2) Mutu pendidikan disekolah akan semakin meningkat

3) Pelaksanaan administrasi disekolah akan berjalan baik

4) Pelaksanaan bimbingan dan penyuluhan terhadap peserta didik akan semakin baik

5) Hubungan antaraguru dengan peserta didik, guru dengan kepala sekolah serta antara sekolah dengan orang tua murid dan dengan masyarakat akan dapat terpelihara dengan lebih baik.

b. Beberapa aspek yang perlu diperhatikan dalam pengembangan karir

Ada beberapa aspek yang perlu diperhatikan dalam pengembangan karir tenaga kependidikan, antara lain:

1) Pemahaman akan tujuan pendidikan dan pengajaran secara jelas dan konkrit

2) Kemampuan untuk memilih bahan pengajaran

3) Kesanggupan untuk memahami problem, minat dan kebutuhan dalam proses belajar anak

4) Kesanggupan untuk mengorganisasi bahan dan pengalaman belajar yang ada atau yang dipunya

c. Moral kerja dan produktivitas kerja Ada beberapa faktor yang mempengaruhi tinggi rendahnya moral kerja seseorang:

1) Faktor minat atau perhatian terhadap pekerjaan

2) Faktor upah atau gaji yang diterima sebagai imbalan dari pekerjaan yang dilakukan

3) Faktor status sosial dari pekerjaan yang bersangkutan

4) Tujuan yang mulia atau tingkat pengabdian yang dipunyai oleh pekerjaan tersebut

5) Faktor suasana kerja dan faktor hubungan kemanusiaan yang ada pada pekerjaan bersangkutan

d. Kesejahteraan pegawai

Sebagai usaha meningkatkan kesejahteraan pegawai negeri sipil tersebut:

1) Taspen, diatur dengan peraturan pemerintah No. 9 tahun 1963 dalam ketentuan tersebutdijelaskan bahwa peserta taspen berhak menerima sejumlah asuransi. Uang tersebut diterima pada saat peserta taspen tersebut berhenti sebagai pegawai negeri sipil.

2) Akses atau asuransi kesehatan, kegiatan ini diatur dengan keputusan presiden No. 230 tahun 1968 tanggal 15 juli 1968.tujuan dari akses untuk memberikan bantuan pemeliharaan kesehatan pegawai negeri sipil, penerima pesiun beserta anggota keluarganya

3) Dan juga dapat mengikuti usaha yang dirancang oleh pemerintah dalam usaha meningkatkan taraf kehisupan pegawai negeri tersebut antara lain 
dengan memeri kesempatan kepada pegawai negeri tersebut untuk ikut serta dalam menggerakkan atau menjadi anggota koperasi pegawai negeri dilingkungan dimana ia berada

e. Pemindahan, pemberhentian dan pensiun

Kepada setiap pegawai negeri sipil diberi kemungkinan untuk dapat pindah dari satu tempat ketempat lainnyakarena alasan- alasan tertentu.Kepindahan tersebut ditujukan untuk menjamin pelaksanaan tugas kenegaraan atau untuk kepentingan kesejahteraanpegawai negeri sipil yang bersangkutan.

Ada beberapa hal yang terjadinya pemberhetian pegawai negeri sipil tersebut antara lain:Permintaan sendiri, Mencapai batas usia lanjut, Adanya peyederhanaan organisasi, Melakukan pelanggaran/ penyelewengan, Tidak sehat jasmani dan rohani, Meninggalkan tugas, Meninggalkan dunia atau hilang.

Hak pension seorang pegawai diatur dalam undangundang No. 11 tahun 1969. Pensiun adalah berhentinya seseorang yang telah selesai menjalankan tugasnya sebagai pegawai negeri sipil karena telah mencapai batas usia yang telah ditentukan atau karena menjalankan hak pensiunnya. Batas usia seseoranf pegawai negeri sipil untuk mendapatkan hak pensiun adalah 56 tahun, batas usia ini dapat diperpanjang menjadi 65 tahun.

\section{f. Kode etik jabatan guru}

Kode etik tenaga keguruan adalah sekumpulan peraturan atau perundang- undang mengenai etika seorang guru sebagai tenagapendidik yang menandung unsure moral, etika, adat istiadat, dan kebiasaan.

Kode etik tenaga keguruan didasarkan pada falsafah pancasila dengan segala azas yang terkandung didalanya dan undang- undang dasar 1945:

1) Guru berbakti untuk membimbing anak didik seutuhnya dalam usaha membentuk manusia pembangunan yang berpancasila

2) Guru memiliki kejujuran professional dalam menerapkan kurikulum sesuai dengan kebutuhan anak didik masing- masing

3) Guru mengkomunikasikan informasi tentang anak didik dan menghindari segala bentuk penyalahgunaan kekuasaan dan wewenang

4) Guru menciptakan suasana kehidupan sekolah dan memelihara hubungan dengan orang tua murid sebaik- baiknya bagi kepentingan anak didik

5) Guru memelihara hubungan baik dengan masyarakat disekitar sekolahnya maupun masyarakat yang lebih luas untuk kepentingan pendidikan

6) Guru secara tersendiri atau bersama- sama berusaha mengembangkan dan meningkatkan mutu profesinya

7) Guru menciptakan dan memeliharahubungan antara sesame guru, baik berdasarkan lingkungan kerja maupun dalam hubungan keseluruhan
8) Guru secara bersama- sama memelihara, meningkatkan dan membina organisasi profesi guru sebagai sarana pengabdian

9) Guru melaksanakan segala ketentuan yang merupakan kebijaksanaan pemerintah dalam bidang pendidikan.

\section{Kesejahteraan PTK}

\section{Penggajian personil}

Penggajian PNS diatur dalam peraturan pemerintah nomor 6 tahun 1997. Besarnya gaji pokok seorang PNS ditentukan oleh golongan ruang, pangkat, dan massa kerjanya. Gaji yang diberikan kepada PNS di samping gaji pokok juga ada tunjangan-tunjangan, di antaranya adalah:

a) Tunjangan keluarga. Tunjangan ini terdiri atas tunjangan istri/ suami sebesar $10 \%$ gaji pokok dan tunjangan anak sebesar 2\% dari gaji pokok untuk masing-masing anak (sebanyak-banyaknya 2 anak).

b) Tunjangan pangan. Diberikan seharga $10 \mathrm{~kg}$ beras untuk setiap anggota untuk sebanyak 4 orang dan bagi yang suami/ istrinya juga PNS, maka hanya diberi satu tunjangan.

c) Tunjangan jabatan. Diberikan kepada PNS yang memangku jabatan tertentu. Tunjangan ini dapat berbentuk tunjangan jabatan structural dan tunjangan jabatan fungsional.

d) Tunjangan lain-lain. Diberikan sesuai dengan peraturan pemerintah. PNS termasuk guru diberi kenaikan gaji pokok, kenaikan gaji berkala, kenaikan gaji istimewa.

\section{Kenaikan pangkat personil}

Kemaikan pangkat adalah penghargaan yang diberikan atas prestasi kerja dan pengabdian PNS terhadap Negara. Meurut PP nomor 99 tahun 2000 jenis kenaikan pangkat PNS adalah sebagai berikut:

a) Kenaikan pangkat regular

b) Kenaikan pangkat pilihan, diberikan kepada PNS yang:

* Menduduki jabatan structural atau jabatan fungsional tertentu

* Menduduki jabatan tertentu yang pengangkatannya ditetapkan dengan keputusan Presiden

* Menunjukkan prestasi kerja luar biasa baiknya

* Menemukan penemuan baru yang bermanfaat bagi Negara

* Diangkat menjadi pejabat Negara

* Melaksanakan tugas belajar dan sebelumnya menduduki jabatan structural atau fungsional

* Telah selesai mengikuti dan lulus tugas belajar

* Dipekerjakan atau diperbantukan secara penuh di luar instansi induknya yang diangkat dalam jabatan pimpinan atau jabatan fungsional tertentu. 
c) Kenaikan pangkat anumerta

d) Kenaikan pangkat pengabdian

\section{Cuti personil}

Cuti PNS menurut pasal 1 PP nomor 24/ 1976 adalah keadaan tidak masuk kerja yang diijinkan dalam jangka waktu tertentu. Jenis cuti PNS menurut peraturan tersebut adalah:

1) Cuti tahunan

2) Cuti besar

3) Cuti sakit

4) Cuti bersalin

5) Cuti karena alas an penting

6) Cuti di luar tanggungan Negara

7) Kesejahteraan pegawai

Selain beberapa hal yang telah disebutkan di atas, pemerintah juga mengusahakan beberapa hal untuk kesejahteraan pegawai negeri sipil yaitu Taspen, Askes, dan Koperasi

\section{KESIMPULAN}

Pendidik profesional dengan tugas utama mendidik, mengajar, membimbing, mengarahkan, melatih, menilai, dan mengevaluasi peserta didik pada pendidikan anak usia dini jalur pendidikan formal, pendidikan dasar, dan pendidikan menengah.

Administrasi pendidik dan tenaga kependidikan adalah proses keseluruhan kegiatan pendidik yang meliputi perencanaan, pengorganisasian, pengarahan, pelaporan, pengkoordinasian, pengawasan dan pembiayaan, dengan menggunakan atau memanfaatkan fasilitas yang tersedia, baik personil, materiil, maupun spirituil untuk mencapai tujuan pendidikan secara efektif dan efisien.

Administrasi pendidik merupakan mediator untuk kelancar dan keberhasil serta peningkatan efektifitas dan lainlain untuk mencapai tujuan pendidikan itu sendiri.

Sekarang, guru harus memperhatikan kepentingankepentingan sekolah, ikut serta menyelesaikan berbagai persoalan yang dihadapi sekolah, yang kadang-kadang sangat kompleks sifatnya, masalah-masalah administratif seperti ini sangat mempengaruhi status profesionil guru.

\section{Daftar Pustaka}

Afriansyah, Hade. 2019. Artikel Konsep Dasar, Proses, dan Ruang lingkup Administrasi Pendidikan. Padang. https://mfr.osf.io/render?url=https://osf.io/emzvn/?direct $\% 26$ mode $=$ render $\% 26$ action $=$ download $\% 26$ mode $=$ rende

Arikunto, suharsimi. 1990.Organisasi dan Administrasi. Jakarta: CV. Raja wali

Asnawir.2005.Administrasi pendidikan. Padang: IAIN IB PRESS

Gunawan, ary. 2002. Administrasi sekolah. Jakarta: PT RINEKA CIPTA
Rifai, Moh. 1984. Administrasi dan supervise pendidikan 1. Bandung: JEMMARS

Sabri, Ahmad. 2000. Administrasi pendidika.Padang: IAIN IB PRESS 